\title{
Determinan Faktor Partisipasi Ibu Balita Dalam Kegiatan Posyandu di Desa Kejawan Putih Tambak Kecamatan Mulyorejo
}

\author{
Pipit Festy Wilianarti' ${ }^{1}$, Aryunani ${ }^{2}$, Eni Sumarliyah ${ }^{3}$ \\ ${ }^{1,2,3}$ Fakultas Ilmu Kesehatan, Universitas Muhammadiyah Surabaya \\ email: pipitbiostat@yahoo.com ${ }^{1}$; eniumsurabaya@gmail.com ${ }^{3}$
}

\begin{abstract}
Implementation of neighborhood health center aims to reduce infant mortalityis accompanied by efforts to reduce the birth rate. For that selected priority programs such asmaternal and child welfare (MCH), family planning, nutrition improvement, immunization andprevention of diarrhea. IHC closely related with active community participation (participationmothers). Factors that influence the participation of mothers in the neighborhood health center activities include knowledge, attitude, affordability of health centers, social, economic, and health workers and cadres factors neighborhood health center.Methods this study uses an analytical methode with cross sectional approach. Total population 95 with a sample of 55 mothers, the samples were taken by simple random sampling. Data were collected by questionnaire and observation, then analyzed using statistical test Regrisi Binary Logistic with significance level of 0.05. The results showed that, the results of statistical tests Binary logistic regression showed knowledge factor $(p=0.000<\alpha=$ $0.05)$, showing the attitude factor $(p=0.002>\alpha=0.05)$ where health care affordability factor indicates $(p=0.003<\alpha=0.05)$, and socioeconomic factors demonstrated $(p=0.010<\alpha=0.05)$ and the factor of health workers and cadres posyandu $(p=0.355>\alpha=0.05)$. Based on these results it can be concluded that the knowledge factor, the affordability of the health service and social economy that affect the mother's participation in growth monitoring sessions.
\end{abstract}

Keywords: IHC, MotherToddler, andparticipation

\section{PENDAHULUAN}

Posyandu sebagai salah satu bentuk Upaya Kesehatan Bersumberdaya Masyarakat (UKBM) yang paling memasyarakat dewasa ini, yang dikelola dari, oleh dan untuk masyarakat. Posyandu dirasakan telah berperan penting dalam meningkatkan sasaran untuk mendapatkan pelayanan kesehatan dasar, seperti KIA (Kesehatan Ibu dan Anak), KB (Keluarga Berencana), Immunisasi, Gizi, serta pencegahan dan penanggulangan diare (Rahaju dkk, 2007). Tujuan penyelenggaraan posyandu salah satunya adalah meningkatkan peran serta masyarakat dalam penyelenggaraan upaya kesehatan dasar. Partisipasi adalah peran serta aktif anggota masyarakat dalam berbagai jenjang kegiatan (Notoatmodjo, 2005). Posyandu erat sekali kaitannya dengan peran serta aktif masyarakat (partisipasi ibu balita).

Partisipasi ibu balita dalam kegiatan posyandu merupakan salah satu faktor pendukung yang sangat diperlukan untuk pemantauan pertumbuhan anaknya. Hal ini dapat dilihat dari keaktifan orangtua membawa anaknya ke posyandu yang mana dapat dilihat dari tren partisipasi masyarakat yang tergambar dari perbandingan antara jumlah anak yang ditimbang dengan seluruh anak yang ada di wilayah tersebut atau D/S. Tingkat partisipasi masyarakat dalam kegiatan posyandu hasilnya minimal harus capai $80 \%$ apabila dibawah $80 \%$ maka dikatakan partisipasi 
mayarakat untuk kegiatan pemantauan pertumbuhan dan perkembangan berat badan sangatlah rendah. Hal ini akan berakibat pada balita tidak akan terpantau oleh petugas kesehatan ataupun kader posyandu dan memungkinkan balita ini tidak diketahui pertumbuhan berat badannya atau pola pertumbuhan berat badannya (Arali, 2008).

Di provinsi Jawa Timur pada tahun 2007 cakupan posyandu berdasarkan SKDN, untuk tingkat partisipasi masyarakat dalam kegiatan posyandu (D/S) yaitu $84,1 \%$. Sedangkan di wilayah Mulyorejo tahun 2013 cakupan posyandu berdasarkan SKDN, untuk tingkat partisipasi masyarakat dalam kegiatan posyandu (D/S) yaitu 80,51\% (Dinas Kesehatan Kota Surabaya, 2013). Pada tahun 2013 cakupan D/S yaitu 85,73\%.

Pelaksanaan posyandu di wilayah kerja Puskesmas Mulyorejo dengan nilai target cakupan kunjungan balita (D/S) pada tahun 2012 ke posyandu yaitu $55,52 \%$, dan

nilai target cakupan kunjungan balita (D/S) pada tahun 2013 yaitu 53,45\% ini berarti nilai kunjungan balita tersebut masih kurang memenuhi target. Penyebab masih kurang memenuhinya target kunjungan balita ke posyandu antara lain rendahnya pengatahuan ibu tentang manfaat dari posyandu dan anggapan ibu bahwa tanpa dibawa ke posyandu balitanya tetap sehat, ada juga ibu yang takut balitanya diimunisasi, karena menganggap setelah diimunisasi nanti anaknya akan panas.

Kurangnya peran petugas kesehatan atau kader dalam memberikan informasi tentang kegiatan posyandu. Pekerjaan ibu balita yang sebagian besar sebagai petani juga mempengaruhi kedatangan ke posyandu, karena waktu pelaksanaan posyandu sering bertepatan dengan waktu dimana mereka harus berangkat kesawah.

Hal ini akan menyebabkan kenaikan BB dan tumbuh kembang anak tidak bisa dipantau, imunisasi tidak dapat dicapai sesuai jadwal. Pengetahuan yang kurang tentang posyandu akan mempengaruhi sikap, ibu untuk berpartisipasi dalam kegiatan posyandu. Kurangnya partisipasi ibu balita dalam kegiatan posyandu dapat dilihat dari faktor aspek perilaku ibu balita diantaranya; pengetahuan, sikap, dan motivasi. Selain itu faktor pekerjaan, pendidikan, sosial ekonomi orang tua yang masih rendah, sehingga menyebabkan ibu balita enggan untuk datang ke posyandu. Kurangnya partisipasi ibu balita juga dipengaruhi oleh faktor eksternal yang meliputi: sosial budaya, dukungan tokoh masyarakat, peran petugas kesehatan, peran kader, dan faktor lingkungan yaitu keterjangkauan jarak antara tempat tinggal dengan pelayanan kesehatan (posyandu) (Dana, 2006). Upaya yang perlu dilakukan dalam rangka meningkatkan partisipasi ibu balita dalam kegiatan posyandu di Desa Kejawan Putih Tambak dengan cara menumbuhkan kesadaran masyarakat khususnya ibu balita tentang pentingnya pelaksanaan kegiatan posyandu bagi kesehatan ibu dan anak.

\section{Konsep Partisipasi Definisi Partisipasi masyarakat}

Partisipasi adalah peran serta aktif anggota masyarakat dalam berbagai jenjang kegiatan. Dilihat dari konteks pembanguna kesehatan, partisipasi adalah keterlibatan masyarakat yang diwujudkan dalam bentuk menjalin kemitraan di antara masyarakat dan pemerintah dalam perencanaan, implementasi dan berbagai aktivitas program kesehatan, mulai dari pendidikan kesehatan, pengembangan program kemandirian dalam kesehatan, sampai dengan mengontrol perilaku masyarakat dalam menanggapi teknologi dan infrastruktur kesehatan (Notoatmodjo, 2005).

\section{Partisipasi ibu balita}

Upaya peningkatan partisipasi ibu dalam membina pertumbuhan dan perkembangan anak balita dilakukan antara lain melalui kegiatan kelompok 
Bina Keluarga Balita (BKB). Di samping itu,

kegiatan posyandu terus ditingkatkan melalui kegiatan imunisasi bagi ibu hamil, Usaha Perbaikan Gizi Keluarga (UPGK), dan penyuluhan tentang pentingnya imunisasi bagi anak balita dan pentingnya Air Susu Ibu (ASI) bagi pertumbuhan dan perkembangan anak balita. Upaya peningkatan peran serta ibu balita dalam masyarakat dilakukan melalui berbagai aktivitas wanita untuk mendukung pembangunan di daerahnya.

Kegiatan tersebut dilaksanakan antara lain melalui wadah pembinaan kesejahteraan keluarga (PKK), Keluarga Berencana (KB), dan posyandu. Melalui gerakan Pembinaan Kesejahteraan Keluarga (PKK), wanita berperan aktif dalam membina kesejahteraan keluarganya, sedangkan dalam kegiatan posyandu, wanita terlibat secara aktif dalam pemberian pelayanan kesehatan, imunisasi, dan perbaikan gizi keluarga. Dibidang Keluarga berencana (KB), peran wanita adalah sebagai peserta dan motivator Keluarga Berencana (KB) (Intanghina, 2008).

\section{Tingkat partisipasi atau peran serta masyarakat}

Mengembangkan peran serta atau partisipasi masyarakat sangat sulit, karena partisipasi masyarakat memerlukan kemampuan, kesempatan dan motivasi. Mantra (1991) dalam Rohayu (2005) mengatakan bahwa peran serta atau partisipasi masyarakat terjadi dalam berbagai tingkatan.

1. Partisipasi masyarakat, karena perintah atau karena paksaan ini diartikan seseorang mau berpartisipasi karena perintah atau dipaksa harus melakukan pekerjaan, jadi tidak karena kesadaran.

2. Partisipasi masyarakat karena imbalan atau insentif, pada bagian ini seseorang mau berpartisipasi karena adanya uang atau ongkos.

3. Partisipasi masyarakat karena identifikasi atau ingin meniru, dalam hal ini seseorang mau berpartisipasi karena sudah melihat hasil yang nyata dan ingin meniru agar dapat berhasil juga.

4. Partisipasi masyarakat karena kesadaran, tingkat partisipasi ini yang bisa langsung dan bertahan karena disadari dengan kesadaran serta kemauan untuk maju.

5. Partisipasi masyarakat karena tuntutan akan hak asasi dan tanggung jawab, partisipasi ini biasanya muncul di negara-negara maju yang berfaham demokrasi sedangkan pada nomor satu sampai empat pada umumnya muncul di negara berkembang.

\section{Kerangka Konsep}

Dalam kerangka konsep ini menggunakan teori Lawrence Green dimana faktor yang mempengaruhi partisipasi ibu balita dalam kegiatan posyandu ada 3 faktor yaitu; 1) faktor predisposisi yang meliputi pengetahuan, sikap, pendidikan, motivasi dan keyakinan 2) faktor pemungkin yaitu Keterjangkauan tempat pelayanan kesehatan, sosial ekonomi 3) faktor penguat yaitu faktor petugas kesehatan dan kader, faktor tokoh masyarakat. Ketiga faktor tersebut akan mempengaruhi partisipasi ibu balita dalam kegiatan posyandu, sehingga akan meningkatkan kegiatan posyandu.

\section{METODE PENELITIAN}

Desain Penelitian Pada penelitian ini menggunakan jenis penelitian analitis yaitu penelitian yang terdiri atas variabel bebas dan variabel terikat (Hidayat, 2007). Dalam penelitian ini peneliti ingin mengetahui faktorfaktor yang mempengaruhi partisipasi ibu balita dalam kegiatan posyandu di Kejawan Putih Tambak.

Pada penelitian ini populasinya adalah Semua ibu balita yang datang dalam kegiatan posyandu. Sampel adalah sebagian dari keseluruhan obyek yang akan diteliti dan dianggap mewakili seluruh ibu balita sejumlah 55 orang, Kriteria inklusi pada penelitian ini : 
1. Ibu yang mempunyai balita umur 0-5 tahun di posyandu

2. Ibu balita yang telah terdaftar dalam kegiatan posyandu lebih dari 3 bulan terakhir.

3. Ibu balita yang tinggal menetap

4. Ibu balita yang bisa membaca dan menulis

5. Ibu balita yang bersedia untuk diteliti dan menandatangani informed concent.

Sampling pada penelitian ini sampel diambil dengan cara simple random sampling yaitu pengambilan sampel dengan cara acak tanpa memperhatikan strata yang ada dalam populasi. Cara ini dilakukan bila anggota populasi dianggap homogen (Hidayat, 2007).

Variabel Penelitian pada penelitian ini variabel independent dan variabel dependent.Variabel Independent pengetahuan, sikap, keterjangkauan tempat pelayanan kesehatan, sosial ekonomi, dan faktor petugas kesehatan dan kader kesehatan. Variabel Dependent partisispasi ibu balita dalam kegiatan posyandu.

Pengumpulan Data dan Analisa

Data sebagai berikut:

a. Instrumen Penelitian Instrumen penelitian ini adalah observasi dan kuesioner.

b. Lokasi penelitian dilakukan di posyandu di desa Kejawan putih tambak Waktu penelitian ini pada bulan Juli sampai Agustus. Analisis Data Untuk mengetahui berbagai faktor yang mempengaruhi partisipasi ibu balita dilakukan analisis dengan uji statistik. Uji yang digunakan untuk mengetahui validitas tes dengan menggunakan uji Regresi Logistik dengan $\alpha=$ 0,05 artinya bila nilai $\rho<0,05$ maka $\mathrm{H} 0$ ditolak, artinya ada pengaruh.

\section{HASIL DAN PEMBAHASAN}

Berdasarkan hasil survey di Posyandu dengan responden sebanyak 95 ibu balita didapatkan data sebagai berikut:
1. Umur

Sebagian besar responden berumur $28-29$ yaitu sebanyak $28,4 \%$ orang dan sebagian kecil respoden berumur 20 - 21 yaitu sebanyak $5,6 \%$.

\section{Pendidikan}

Sebagian besar pendidikan responden adalah SMP yaitu sebanyak 81 orang $(58 \%)$ dan sebagian kecil pendidikan responden adalah Perguruan Tinggi yaitu sebanyak 3 orang (2\%).

\section{Pekerjaan}

Tabel 5.1 Distribusi karakteristik responden berdasarkan pekerjaan di Posyandu

\begin{tabular}{|c|c|c|}
\hline Pekerjaan & Frekuensi & $\begin{array}{c}\text { Presentase } \\
(\%)\end{array}$ \\
\hline Tidak & & \\
Bekerja & 41 & 30 \\
Petani & 84 & 60 \\
Pegawai & 13 & 9 \\
Swasta & 1 & 1 \\
PNS & & 100 \\
\hline Total & 95 & \\
\hline
\end{tabular}

Dari hasil penelitian pada tabel 5.1 menunjukkan bahwa sebagian besar pekerjaan responden adalah petani yaitu sebanyak 84 orang (60\%) dan sebagian kecil pekerjaan responden adalah PNS yaitu sebanyak 1 orang (1\%).

\section{Data Khusus}

\section{Pengetahuan}

Dari hasil penelitian didapatkan data tentang pengetahuan ibu balita di kelompokkan pada tabel 5.2 dibawah ini:

Tabel 5.2. Distribusi karakteristik responden berdasarkan pengetahuan di Posyandu

\begin{tabular}{|c|c|c|c|}
\hline No. & Pengetahuan & Frekuensi & $\begin{array}{c}\text { Presentasi } \\
(\%)\end{array}$ \\
\hline 1. & Kurang & 48 & 50.5 \\
2. & Cukup & 30 & 31.6 \\
3. & Baik & 17 & 17.9 \\
\hline & Total & 95 & 100 \\
\hline
\end{tabular}

Dari hasil penelitian tabel 5.2 menunjukkan bahwa sebagian besar pengetahuan responden kurang yaitu sebanyak 48 orang $(50.5 \%)$ dan sebagian kecil pengetahuan respoonden baik yaitu sebanyak 17 orang (17.9\%). 


\section{Sikap}

Dari hasil penelitian didapatkan gambaran tentang sikap ibu balita dikelompokkan pada tabel 5.3dibawah ini:

Tabel 5.3 Distribusi karakteristik responden berdasarkan sikap di Posyandu

\begin{tabular}{|c|c|c|c|}
\hline No. & Sikap & Frekuensi & $\begin{array}{c}\text { Presentase } \\
(\%)\end{array}$ \\
\hline 1. & Kurang & 40 & 42.1 \\
2. & Cukup & 34 & 35.8 \\
3. & Baik & 21 & 22.1 \\
\hline & Total & 95 & 100 \\
\hline
\end{tabular}

Dari hasil penelitian pada tabel 5.3 menunjukkan bahwa sebagian besar sikap responden kurang yaitu sebanyak 40 orang (42\%) dan sebagian kecil sikap responden baik yaitu sebanyak 21 orang $(22.1 \%)$.

\section{Keterjangkauan Tempat \\ Pelayanan Kesehatan}

Dari hasil penelitian didapatkan gambaran tentang keterjangkauan tempat pelayanan kesehatan ibu balita:

Tabel 5.4 Distribusi karakteristik responden berdasarkan keterjangkauan tempat pelayanan kesehatan di Posyandu

\begin{tabular}{|c|c|c|c|}
\hline No & $\begin{array}{c}\text { Keterjangkaua } \\
\text { n Tempat } \\
\text { Pelayanan } \\
\text { Kesehatan }\end{array}$ & $\begin{array}{c}\text { Frekuens } \\
\text { i }\end{array}$ & $\begin{array}{c}\text { Presentas } \\
\text { e (\%) }\end{array}$ \\
\hline 1. & Jauh & 57 & 60 \\
2. & Dekat & 38 & 40 \\
\hline & Total & 95 & 100 \\
\hline
\end{tabular}

Dari hasil penelitian pada tabel 5.4 menunjukkan bahwa sebagian besar keterjangkauan tempat pelayanan kesehatan responden jauh yaitu sebanyak 57 orang (60\%) dan sebagian kecil keterjangkauan tempat pelayanan kesehatan responden yaitu sebanyak 38 orang (40\%).

\section{Sosial ekonomi}

Dari hasil penelitian didapatkan gambaran tentang sosial ekonomi ibu balita dikelompokkan pada tabel 5.5 dibawah ini :
Tabel 5.5 Distribusi karakteristik responden berdasarkan sosial ekonomi di Posyandu

\begin{tabular}{|c|c|c|c|}
\hline No. & $\begin{array}{c}\text { Sosial } \\
\text { Ekonomi }\end{array}$ & Frekuensi & $\begin{array}{c}\text { Presentase } \\
(\%)\end{array}$ \\
\hline 1. & Rendah & 58 & 61 \\
2. & Sedang & 28 & 29 \\
3. & Tinggi & 9 & 10 \\
\hline & Total & 95 & 100 \\
\hline
\end{tabular}

Dari hasil penelitian pada tabel 5.5 menunjukkan bahwa sebagian besar sosial ekonomi responden rendah yaitu sebanyak 58 orang $(61 \%)$ dan sebagian kecil sosial ekonomi responden tinggi yaitu sebanyak 9 orang (10\%).

\section{Faktor Petugas dan Kader Posyandu}

Dari hasil penelitian didapatkan gambaran tentang faktor petugas dan kader posyandu ibu balita dikelompokkan pada tabel dibawah ini:

Tabel 5.6 Distribusi karakteristik responden berdasarkan faktor petugas dan kader posyandu di Posyandu

\begin{tabular}{|c|c|c|c|}
\hline No. & $\begin{array}{c}\text { Faktor } \\
\text { petugas } \\
\text { kesehatan } \\
\text { dan kader } \\
\text { posyandu }\end{array}$ & Frekuensi & Presentase \\
\hline 1. & Kurang & 52 & 55 \\
2. & Cukup & 33 & 34.5 \\
3. & Baik & 10 & 10.5 \\
\hline & Total & 95 & 100 \\
\hline
\end{tabular}

Dari hasil penelitian pada tabel 5.6 menunjukkan bahwa sebagian besar faktor petugas kesehatan dan kader posyandu terhadap responden kurang yaitu sebanyak 52 orang $(55 \%)$ dan sebagian kecil faktor petugas kesehatan dan kader posyandu terhadap responden baik yaitu sebanyak 10 orang $(10 \%)$.

\section{Partisipasi}

Dari hasil penelitian didapatkan gambaran partisipasi ibu balita dikelompokkan pada tabel dibawah ini:

Tabel 5.7 Distribusi karakteristik responden berdasarkan partisipasi di Posyandu

\begin{tabular}{|c|c|c|c|}
\hline No & Partisipasi & Frekuensi & $\begin{array}{c}\text { Presentase } \\
(\%)\end{array}$ \\
\hline 1. & Kurang & 67 & 70 \\
2. & Baik & 28 & 29 \\
\hline & Total & 95 & 100 \\
\hline
\end{tabular}


Dari hasil penelitian pada tabel 5.7 menunjukkan bahwa sebagian besar partisipasi responden kurang yaitu sebanyak 67 orang $(70 \%)$ dan sebagian kecil partisipasi responden baik yaitu sebanyak 28 orang (29\%).

Tabel.5.8 Determinan factor partisipasi ibu balita pada posyandu Kejawanputih Tambak Kecamatan Mulyorejo 2014

\begin{tabular}{|c|c|c|c|}
\hline No & Variabel & Sig & Hasil \\
\hline 1. & Pengetahuan & 0.000 & $\begin{array}{c}\text { Ada } \\
\text { pengaruh }\end{array}$ \\
\hline 2. & Sikap & 0.002 & $\begin{array}{c}\text { Ada } \\
\text { pengaruh }\end{array}$ \\
\hline 3. & $\begin{array}{c}\text { Keterjangkauan } \\
\text { pelayanan }\end{array}$ & 0.003 & $\begin{array}{c}\text { Ada } \\
\text { pengaruh }\end{array}$ \\
\hline 4. & $\begin{array}{c}\text { Petugas } \\
\text { kesehatan }\end{array}$ & 0.355 & $\begin{array}{c}\text { Tidak ada } \\
\text { pengaruh }\end{array}$ \\
\hline 5. & Social ekonomi & 0,01 & $\begin{array}{c}\text { Ada } \\
\text { pengaruh }\end{array}$ \\
\hline
\end{tabular}

Hasil penelitian menunjukkan bahwa, hasil uji statistik Regresi Logistik Binary faktor pengetahuan menunjukkan $(\mathrm{p}=0,000<\alpha=0,05)$, faktor sikap menunjukkan $(\mathrm{p}=0,002>\alpha=0,05)$ faktor keterjangkauan tempat pelayanan kesehatan menunjukkan $(\mathrm{p}=0,003<\alpha=$ $0,05)$, dan faktor sosial ekonomi menunjukkan $(\mathrm{p}=0,010<\alpha=0,05)$ dan faktor petugas kesehatan dan kader posyandu $(\mathrm{p}=0,355>\alpha=0,05)$.

\section{PEMBAHASAN}

Faktor faktor yang mempengaruhi partisipasi ibu dalam kegiatan posyandu dalam peneliatian ini antara lain adalah.

\section{Pengetahuan}

Menurut teori Konjoroningrat (1997: 163) yang dikutip oleh Nursalam menyebutkan bahwa makin tinggi tingkat pendidikan seseorang makin mudah menerima informasi sehingga makin banyak pula pengetahuan yang di miliki seseorang.Hasil uji statistic diketahui $\mathrm{p}=$ $0,000<\alpha=0,05$.hail penelitian dapat dinyatakan ada pengaruh pengetahuan dengan partisipasi masyrakat dalam berkunjung keposyandu. Banyak faktor yang mendukung ibu datang keposyandu antara lain niat ibu agar dapat mendapatkan manfaat kesehatan untuk anak, selain itu adalah banyaknya informasi yang diperoleh ibu tentang pentingnya melakukan deteksi terhadap perkembangan anak yang dapat dilaksanakan di posyandu. Mengembangkan peran serta atau partisipasi masyarakat sangat sulit, karena partisipasi masyarakat memerlukan kemampuan, kesempatan dan motivasi. Mantra (1991) dalam Rohayu (2005) mengatakan bahwa peran serta atau partisipasi masyarakat terjadi dalam berbagai tingkatan.

\section{Sosial-ekonomi}

Hasil penelitian menunjukkan bahwa faktor sosial ekonomi $(\mathrm{p}=0,010<\alpha=$ 0,05 . Berarti ada pengaruh sosial ekonomi ibu dengsn partisipasi ibu dalam mengikuti kegiatan di posyandu. Seorang ibu bekerja biasanya karena beberapa alasan, tetapi yang sering karena perlunya pemenuhan kebutuhan finansial, yang dimaksud bekerja di sini adalah kegiatan yang dilakukan oleh seorang secara rutin dan diikuti perolehan imbalan.Pekerjaan adalah aktivitas yang dijalani secara terus menerus yang berhubungan dengan kesibukan seseorang. posyandu diselenggarakan pada hari kerja dan jam kerja kegiatan posyandu diselenggarakan mulai jam 09.00-12.00 WIB pada hari kerja. Selain ibu bekerja, ibu balita pendatang merupakan ibu balita yg kurang aktif dlm kegiatan posyandu, sedangkan bagi ibu balita dari keluarga yang mampu merasa sudah membawa anaknya ke dokter, sehingga menganggap tidak perlu dibawa ke posyandu untuk penimbangan (Yanyan, 2008).

Menurut Yanyan (2008) status sosial ekonomi menggambarakan tingkat penghidupan seseorang atau keluarga yang

ditentukan oleh unsur pendidikan, pekerjaan dan penghasilan. Status ekonomi juga berkaitan dengan konsumsi (pengeluaran) dan produksi (pendapatan). Status ekonomi mempengaruhi kebutuhan seseorang karena menentukan kemampuan keluarga untuk memperoleh makanan, karena pemenuhan kebutuhan hidupnya tergantung dari penghasilannya. Juga 
berpengaruh terhadap pemilihan kebutuhan akan pelayanan kesehatan. Tingkat penghasilan juga merupakan faktor sosial ekonomi yang secara tidak langsung akan mempengaruhi partisipasi dalam kegiatan posyandu dimana semakin besar tingkat penghasilan maka semakin baik partisipasi dalam kegiatan posyandu. Tingkat penghasilan akan menentukan kemampuan untuk memenuhi kebutuhan.

Pendidikan menurut indikator kesejahteraan rakyat (2007) "Pendidikan terdiri atas pendidikan formal dan non formal, jenjang pendidikan formal terdiri atas pendidikan dasar (SD), pendidikan menengah (SMP dan SMA), dan pendidikan tinggi (Akademi dan Universitas), jenjang pendidikan non formal terdiri dari seperti kursus mengetik, menjahit, komputer, bahasa inggris dan lain sebagainya. Pendidikan adalah proses pengubahan sikap atau tingkah laku seseorang atau kelompok orang dalam usaha mendewasakan manusia melalui upaya pengajaran dan pelatihan.

Pendidikan adalah tahapan pendidikan yang ditetapkan berdasarkan tingkat perkembangan peserta didik, tujuan yang akan dicapai, dan kemampuan yang dikembangkan. Pada penelitian ini pengukuran variabel tingkat pendidikan dapat digolongan berdasarkan undangan-undang RI tentang sistem pendidikan rasional tahun 2003 yaitu: pendidikan dasar terdiri SD dan SMP, pendidikan menengah terdiri dari SMA sederajat, pendidikan tinggi terdiri dari diploma, sarjana, magister, spesialis (Yanyan, 2008).

\section{Sikap (Attitude)}

Berdasarkan hasil penelitian didapatkan, faktor sikap menunjukkan $(\mathrm{p}=0,002>\alpha$ 0,05). Sikap merupakan reaksi atau respon yang masih tertutup dari seseorang terhadap suatu stimulus atau objek. Newcomb dalam Notoatmodjo (2005), mengatakan sikap merupakan kesiapan atau kesediaan untuk bertindak dan bukan merupakan pelaksanaan motif tertentu. Ibu balita akan mengambil sikap terhadap posyandu setelah tahu manfaat pelaksanaan program posyandu dan program kesehatan lainnya.

Menurut Notoadmodjo (2010), sikap mempunyai 3 komponen salah satunya komponen afektif merupakan aspek penilaian atau evaluatif terhadap objek. Komponenafektif adalah aspek emosional yang berkaitan dengan penilaian terhadap apa yang diketahui manusia. Setelah seseorang mempunyai pemahaman atau pengetahuan terhadap stimulus atau kondisi eksternalnya. Hasilnya adalah penilaian atau pertimbangan terhadap pengetahuan tersebut. Seperti contoh diatas, ibu yang telah mempunyai pengetahuan tentang gunanya imunisasi untuk mencegah penyakit bagi anaknya. Pengetahuan ini selanjutnya akan diolah ibu dengan melibatkan emosinya.

\section{Keterjanggkauan Tempat Pelayanan}

Kesehatan Berdasarkan hasil penelitian didapatkan bahwa, faktor keterjangkauan tempat pelayanan kesehatan menunjukkan $(\mathrm{p}=0,003<\alpha=$ $0,05)$. Sehingga dapat dinyatakan ada pengaruh keterjangkauan dalam meberperan aktif diposyandu. Menurut Muhaemin (2008) letak geografis dapat mempengaruhi terhadap partisipasi ibuibu yang mempunyai balita untuk menimbangkan balitanya ke Posyandu. masyarakat yang merasa jauh ke tempat lokasi dan memerlukan biaya tambahan transportasi untuk mencapai lokasi. Untuk terwujudnya suatu sikap ke dalam tindakan diperlukan suatu faktor pendukung (enabling factor) antara lain keterjangkauan fasilitas Posyandu.

Posyandu yang mudah dicapai kemungkinan besar akan digunakan oleh responden dan bila sulit dicapai jaraknya terlalu jauh dari jangkauan kemungkinan besar tidak akan terpakai oleh responden maupun ibu-ibu untuk menimbangkan balitanya. Salah satu model variabel dari perilaku kesehatan adalah model sumber 
daya masyarakat yang salah satu unsurnya adalah penyediaan pelayanan dan ketercapaian dari pelayanan kesehatan yang tersedia.

\section{SIMPULAN}

Dari hasil penelitian mengenai Determinan factor dapat disimpulkan sebagai berikut: Hasil penelitian menunjukkan bahwa, faktor yang mempengaruhi partisipasi ibu dalam kegiatan posyandu diKejawan Putih Tambak adalah: faktor pengetahuan, faktor sikap menunjukkan faktor keterjangkauan tempat pelayanan kesehatan, dan faktor sosial ekonomi.

\section{DAFTAR PUSTAKA}

Ambarwati ER, Rismintari YS. AsuhanKebidanan Komunitas. Nuha Medika. Yogyakarta

Arali. (2008). Catatan Ringan Tentang Perkembangan Posyandu. http://wordpress.com. Di akses tanggal 25 Maret 2010

Dana, IN. (2006). Upaya MeningkatanPeran Serta

Masyarakat Melalui Analisis Faktor Stakeholder Posyandu Di Wilayah Kerja Puskesmas Denpasar Timur Kota Denpasar. http://adln.lib.unair.ac.id.

Di akses tanggal 15 Maret 2014

Departemen Kesehatan. (2006). Pedoman Umum Pengelolaan Posyandu. Jakarta

Dinas Kesehatan. (2008). Profil Kesehatan Bojonegoro.Bojonegoro

Hidayat, Alimul A. (2007). Metode Penelitian Keperawatan dan Teknik Analisis Data. Salemba Medika. Jakarta

Intanghina. (2008). Peran Serta IbuBalita Dalam Kegiatan Penimbangan.

http://wordpress.com. Di akses tanggal 5April 2014
Muhaemin, A (2008). Beberapa Faktor Yang Berhubungan Dengan Partisipasi Ibu Balita Dalam Kegiatan Penimbangan Di Posyandu (Studi Kasus Di Desa Sidorejo Bendosari Sukoharjo). http://wordpress.com. Di akses tanggal 16 Maret 2014

Notoatmodjo,S. (2003). Pendidikan danPerilaku Kesehatan. Renika Cipta. Jakarta

Notoatmodjo,S. (2005). Promosi Kesehatan Teori dan Aplikasi. Renika Cipta. Jakarta

Notoatmodjo,S. (2007). Kesehatan Masyarakat Ilmu dan Seni. Renika Cipta.Jakarta

Notoatmodjo,S. (2010). Ilmu Perilaku Kesehatan . Renika Cipta. Jakarta

Nursalam. (2008). Konsep dan Penerapan Metodologi Penelitian IlmuKeperawatan Pedoman Skripsi, Tensis, dan Instrumen Penelitian Keperawatan.Salemba Medika. Jakarta

Oktavira, AT. (2007). Penerapan Indikator Peran Serta Masyarakat Dalam Kegiatan Posyandu Di Kelurahan Dupak Surabaya.

http://adln.lib.unair.ac.id. Di akses tanggal 5 April 2010

Rahaju, B dkk.(2007).Buku Pegangan Kader Posyandu. Dinas kesehatan propinsi Jawa Timur.

Rohayu, SB. (2005). Beberapa Faktor Yang Berhubungan Dengan Partisipasi Kader Posyandu Di Wilayah Puskesmas Kedung Solo Kabupaten Sidoarjo Jawa Timur. http://adln.lib.unair.ac.id. Di akses tanggal 10 April 2014 